\title{
H2AC14 wt Allele
}

National Cancer Institute

\section{Source}

National Cancer Institute. H2AC14 wt Allele. NCI Thesaurus. Code C162914.

Human H2AC14 wild-type allele is located in the vicinity of $6 \mathrm{p} 22.1$ and is approximately 1 $\mathrm{kb}$ in length. This allele, which encodes histone H2A type 1-J protein, is involved in DNA wrapping and compaction. 